\title{
Forage production in mixed grazing systems of elephant grass with arrowleaf clover or forage peanut $\mathbf{t}^{1}$
}

\author{
Daiane Cristine Seibt ${ }^{2}$, Clair Jorge Olivo ${ }^{2}$, Vinicius Alessio ${ }^{2}$, Aline Rodrigues Silva ${ }^{2}$, \\ Maurício Pase Quatrin ${ }^{2}$, Amanda Nunes Assis dos Anjos ${ }^{2}$
}

10.1590/0034-737X201865020009

\begin{abstract}
Most dairy production systems are pasture-based, usually consisting of sole grass species. This system facilitates pasture management, but results in high production costs, mainly because of nitrogen fertilizers. An alternative to making forage systems more sustainable is to introduce legumes into the pasture. Mixed pastures allow better forage distribution over time and reduce fertilization costs. Thus, the objective of this study was to evaluate, throughout the year, three forage systems (FS): FS1 (control) - elephant grass (EG), ryegrass (RG), and spontaneous species (SS); FS2 $-\mathrm{EG}+\mathrm{RG}+\mathrm{SS}+$ arrowleaf clover; and FS3 $-\mathrm{EG}+\mathrm{RG}+\mathrm{SS}+$ forage peanut. Elephant grass was planted in rows spaced $4 \mathrm{~m}$ apart. Ryegrass was sown between the EG lines, in the winter. Arrowleaf clover was sown according to the respective treatments and forage peanut was preserved. Evaluation was carried out using Holstein cows. The experiment was arranged in a completely randomized design, with three treatments (FS), and three repetitions (paddocks) with repeated measurements (grazing cycles). Forage mass achieved 3.46, 3.80, and $3.91 \mathrm{tha}^{-1}$ for the treatments FS1, FS2 and FS3, respectively. The forage systems intercropped with legumes produced the best results.
\end{abstract}

Keywords: Arachis pintoi; Pennisetum purpureum; Trifolium vesiculosum.

\section{RESUMO}

\section{Produção de forragem em sistemas forrageiros de capim elefante consorciados com trevo vesiculoso ou amendoim forrageiro}

Os sistemas de produção leiteira, em sua maioria, utilizam as pastagens como base da alimentação dos animais, geralmente, constituídas apenas por gramíneas. Essa prática simplifica o manejo dos pastos, contudo, implica em custos elevados de produção, notadamente pelo uso de adubos nitrogenados. Uma alternativa para tornar os sistemas forrageiros mais sustentáveis é a introdução de leguminosas, possibilitando melhor distribuição de forragem no decorrer do tempo, além de reduzir custos com adubação. Assim, o objetivo desta pesquisa foi avaliar, ao longo do ano, três sistemas forrageiros (SF) com capim elefante (CE), azevém (AZ), espécies de crescimento espontâneo (ECE), como $\mathrm{SF} 1$ (testemunha); $\mathrm{CE}+\mathrm{AZ}+\mathrm{ECE}+$ trevo vesiculoso, como SF2; e CE + AZ + ECE + amendoim forrageiro, como SF3. O capim elefante foi estabelecido em linhas afastadas a cada $4 \mathrm{~m}$. No período hibernal realizou-se a semeadura do azevém entre as linhas de CE; e considerando os respectivos tratamentos o trevo vesiculoso foi semeado e o amendoim forrageiro foi preservado. Para avaliação foram usadas vacas da raça Holandesa. O delineamento experimental utilizado foi o inteiramente casualizado, com três tratamentos (SF), três repetições (piquetes) com medidas repetidas (pastejos). Os valores de massa de forragem foram de 3,46; 3,80 e 3,91 tha-1, respectivamente para os tratamentos SF1, SF2 e SF3. Melhores resultados foram obtidos nos sistemas forrageiros consorciados com leguminosas.

Palavras-chave: Arachis pintoi; Pennisetum purpureum; Trifolium vesiculosum.

Submitted on April $1^{s t}, 2015$ and accepted on January $16^{\text {th }}, 2018$.

${ }^{1}$ This work is part of the first author's Master Dissertation.

${ }^{2}$ Universidade Federal de Santa Maria, Departamento de Zootecnia, Santa Maria, Rio Grande do Sul, Brazil. daianeseibt_np@yahoo.com.br; clairolivo@yahoo.com.br; viniciusalessio@hotmail.com; alininharodrigues.silva@hotmail.com; mauricio.quatrin@gmail.com; assiszoot@yahoo.com.br

*Corresponding author: daianeseibt_np@yahoo.com.br 


\section{INTRODUCTION}

Pastures are the main source of animal feed, especially grass pastures. The predominant pasture system is based on the conventional single crop condition. Monocropping simplifies pasture management; however, imply higher production costs because of the high use of nitrogen fertilizers (Olivo et al., 2007).

An alternative to making forage systems more sustainable is the introduction of legumes (Skonieski et al., 2011). This strategy allows a better distribution of forage over time, contributes to balance the supply and quality of forage, reduces costs with fertilization, and minimizes environmental impacts by reducing the use of nitrogen fertilizers (Assmann et al., 2004). Forage legumes, besides contributing to animal production, are crucial for raising productivity and sustaining pastures (Barcellos et al., 2008). However, the difficult implantation and the low persistence of legumes in production systems have been the main causes of the low level of adoption of the mixed forage systems. Surveys indicate that only $2 \%$ of pasture areas in Brazil use legumes (Dall'agnol et al., 2002).

Among forage species, elephant grass (Pennisetum purpureum Schum.) stands out for the high forage potential and easy adaptation to the climate conditions prevailing in nearly all the country's regions. It is mostly grown as a monocrop, with production concentrated in summer. Thus, the intercropping of this species with other grasses combined with the introduction of legumes such as forage peanuts or clover may become an important production strategy. Usually, mixed and intercropped forage species contribute to balance the supply and the quality of forage, considering that the production of these species peaks at different times, extending grazing time (Azevedo Junior et al., 2012; Diehl et al., 2014). In this context, this study aimed at evaluating pre- and postgrazing forage mass and forage production in three forage systems, consisting of elephant grass, ryegrass, spontaneous species, and two legumes (arrowleaf clover or forage peanut) during one agricultural year.

\section{MATERIALAND METHODS}

The experiment was conducted in an area of the Laboratory of Dairy Cattle, belonging to the Department of Animal Science of the Federal University of Santa Maria (UFSM), Santa Maria - RS, from May 2013 to April 2014. The soil of the area is classified as dystrophic sandy Red Argisol, of the São Pedro Soil Mapping Unit (Streck et al., 2002). The climate of the region is of the type Cfa (subtropical humid) according to the classification of Köppen (Moreno, 1961).

Average monthly temperature and rainfall during the experimental period (May 2013 to April 2014) were $19.4^{\circ} \mathrm{C}$ and $130.8 \mathrm{~mm} \mathrm{month}^{-1}$ (INMET, 2014), espectively; the average of the climatological normal for the respective period are $19.2^{\circ} \mathrm{C}$ and $140.5 \mathrm{~mm} \mathrm{month}^{-1}$ (Wrege et al., 2011). Frosts recorded during May, June, July, August, and September 2013 were three, four, six, four, and two, respectively (INMET, 2014).

Experimental evaluation was carried out in an area of 0.49 ha divided into nine paddocks. The treatments consisted of three forage systems based on elephant grass (Pennisetum purpureum Schum.) cv. Merckeron Pinda; ryegrass (Lolium multiflorum Lam.), and species of spontaneous growth, with the introduction of arrowleaf clover or forage peanut.

The experimental area has been kept with elephant grass since 2004, in rows spaced $4 \mathrm{~m}$ apart. In May 2013, according to the forage system, arrowleaf clover (Trifolium vesiculosum Savi) cv. Yuchi seeds were sown by broadcasting, after scarification and inoculation, at the rate of $10 \mathrm{~kg} \mathrm{ha}^{-1}$. The forage peanut (Arachis pintoi Krap. \& Greg.), cv. Amarillo was preserved. It had been established in 2006, manually sown using hand jab planters, in $0.50 \mathrm{~m}$ row spacing and rate of $12 \mathrm{~kg} \mathrm{ha}^{-1}$. Then, in all experimental area, only between the rows, harvest was undertaken close to the ground and seeds of ryegrass cv. Comum were sown at the rate of $30 \mathrm{~kg}$ of ha-1. In September, elephant grass was cut at $20 \mathrm{~cm}$ above soil level, approximately. In January 2014, only between the rows, another harvest was undertaken close to the ground.

Base fertilization was carried out for the intercrop grasslegume, based on soil analysis, as recommended by the Manual of Fertilization and Liming for the States of Rio Grande do Sul and Santa Catarina (CQFS, 2004). The average amount recommended for the winter and summer applied was $60 \mathrm{~kg} \mathrm{ha}^{-1}$ year-1 of both $\mathrm{P}_{2} \mathrm{O}_{5}$ and $\mathrm{K}_{2} \mathrm{O}$. The nitrogen fertilization in the winter was $30 \mathrm{~kg}$ of $\mathrm{N} \mathrm{ha}^{-1}$, in the form of urea, divided in two applications and in the summer was $100 \mathrm{~kg}$ of $\mathrm{N} \mathrm{ha}^{-1}$ divided in four applications between November 2013 and February 2014.

The criterion for the beginning of grazing during the winter was the ryegrass height with approximately $20 \mathrm{~cm}$. In the summer, the criterion was the height of the elephant grass canopy, between 100 and $120 \mathrm{~cm}$. The grazing method used was rotational stocking, with one to two days of period of occupation.

In November 2013, spittlebugs (Deois flavopicta) were detected in the pasture. The control was carried out with the biological product METARRIL ${ }^{\circledR}$, which is a biological pesticide whose active ingredients are spores of the fungus Metarhizium anisopliae.

Forage mass was estimated using a double sampling technique adapted from 't Mannetje (2000). Before the cows entry the area and after they leave it, with 20 visual estimates and 5 destructive cuttings, individually for elephant grass and between rows. The cuttings were done on the tussocks formed by the elephant grass to a height of $50 \mathrm{~cm}$ and close 
to the ground between the rows. The cutting samples were weighed and a sub-sample was taken to determine the botanical composition of the pasture and the structure of the elephant grass. These components were dried in forced air oven at $55^{\circ} \mathrm{C}$ to constant weight to determine the participation of each component based on the dry matter.

Before sampling, the height of the canopy was measured, as well as the width of the elephant grass tussocks, which occupied on average $22 \%$ of the area. This value and that of the area occupied by forage between the rows $(78 \%)$ were used later to determine the forage production per unit area.

To determine the stocking density, there were maintained the forage supply between 6 and $12 \mathrm{~kg}$ of DM $100 \mathrm{~kg}$ of body weight ${ }^{-1}$ for the mass present between rows and $4 \mathrm{~kg}$ of DM $100 \mathrm{~kg}$ of body weight ${ }^{-1}$ for the biomass of leaf blades of elephant grass, based on the pre-grazing mass. Holstein lactating cows with a mean body weight of $570 \mathrm{~kg}$ and an average production of 19.5 $\mathrm{kg}$ of day ${ }^{-1}$ milk were used for the evaluation. The cows received food supplementation at the ratio of $0.9 \%$ of body weight, based on corn, soybean meal, and mineral premix. If they were not in the experimental areas, the animals were kept on seasonal pastures, with oats and ryegrass during the winter and Cynodon and elephant grass in the summer, receiving the same food supplementation.

Grazing efficiency was estimated by the difference between the forage mass before grazing and after grazing transformed into percentage (Hodgson, 1979). The forage production of each grazing cycle was calculated by the difference between the pre-grazing forage mass and the residual forage mass of the previous grazing. The accumulation rate was determined by dividing the forage yield of each grazing cycle by the number of days comprised between the grazing cycles considered.

The experiment was arranged in a completely randomized design with three treatments (forage systems) and three repetitions of areas (paddocks) with repeated measures (grazing cycles). The mean grazing data were examined by analysis of variance, and when a significant interaction effect was found between the forage system and grazing cycle, the means were compared by the Student's T test, at the level of $5 \%$ of probability, using the MIXED procedure (SAS, 2001). In the absence of interaction, the effect of forage system was tested. Correlation analysis was performed to confirm the association. The following mathematical model was used: $\mathrm{Y}_{\mathrm{ijk}}=\mathrm{m}+\mathrm{S}_{\mathrm{i}}+\mathrm{R}_{\mathrm{j}}\left(\mathrm{S}_{\mathrm{i}}\right)+\mathrm{C}_{\mathrm{k}}+(\mathrm{SC})_{\mathrm{ik}}+\varepsilon_{\mathrm{ijk}}$, where $\mathrm{Y}_{\mathrm{ijk}}$ represents the dependent variables; $\mathrm{m}$ is the mean of all observations; $S_{i}$ is the effect of forage system; $R_{j}\left(S_{i}\right)$ is the effect of repetition within the forage system (error a); $\mathrm{C}_{k}$ is the effect of grazing cycle; $(\mathrm{SC})_{\mathrm{ik}}$ represents the interaction between forage system and grazing cycle; $\varepsilon_{\mathrm{ijk}}$ is the residual effect (error b).
The experimental project was approved by the Ethics and Biosafety Committee of UFSM by the opinion 113/ 2011 under the protocol $n^{\circ} 23081016073 / 2011$.

\section{RESULTS AND DISCUSSION}

During the evaluation period, between May 2013 and April 2014, eight grazing cycles were conducted in forage systems. The stocking period ranged from one to two days, with an average rest period of 40 and 32 days, for the winter and summer periods, respectively. The average cycle observed in the winter is considered long according to Silva Neto et al. (2006). The authors conducted a study with ryegrass using modeling techniques to compare methods of continuous and rotational stocking and found that rotation cycles of 30 days and 29 days of rest resulted in higher forage consumption. The analysis of the duration of grazing cycles in the summer showed that short periods of occupation of up to three days and resting close to 30 days for warm-season species such as elephant grass are associated with better quality forage and animal performance (Soares et al., 2004).

Interaction $(\mathrm{P} \leq 0.05)$ was found between forage systems and grazing cycles for most variables, except for the fractions elephant grass and dead material of this species (Table 1). This resulted from the varied composition of the forage systems, with the presence of winter and summer cycle species, in addition to legumes. Meteorological variables such as temperature, photoperiod, and rainfall distribution also interfered with forage production throughout the year.

No differences were found for the forage mass (pregrazing) in grazing between August and November. In the following cycles, the highest values were recorded in the intercropping treatments. This result was due, in particular, of the contribution of elephant grass, while in the intercropping with forage peanut it was due to the participation of the legume. The average forage mass for the intercropping treatments was $3.86 \mathrm{t} \mathrm{ha}^{-1}$, which was similar to that reported by Azevedo Junior et al. (2012), of $3.63 \mathrm{t} \mathrm{ha}^{-1}$, and higher than that found by Diehl et al. (2014), of $2.8 \mathrm{tha}^{-1}$, using similar systems.

There were found differences $(\mathrm{P} \leq 0.05)$ for the elephant grass participation among the forage systems in four of the six grazing areas where it was present. It was superior in the system with arrowleaf clover from January and was equal to the system with forage peanut in April. These differences were possibly due to the residual effect of the nitrogen contribution by the legumes to the system, providing better developmental conditions for the companion grass (Pereira, 2001). Interestingly, there was a low participation of the dead elephant grass fraction in all forage systems, around $2 \%$.

Differences $(\mathrm{P} \leq 0.05)$ were found for the fraction of spontaneous species, with the highest participation of 
these species in the non-legume system. The differences among the systems demonstrated that the presence of legumes exerted control over these species (Teodoro et al., 2010). The lower participation of the intercropping with arrowleaf clover in relation to forage peanut and its absence in the grazing from January led to an increase in spontaneous species, which was also likely due to input of nutrients to the system (Pereira, 2001). This condition favored, especially, the development of Buffalo grass
(Paspalum conjugatum). Other species such as Bermuda grass (Cynodon spp.), country mallow (Sida spp.), plantain signalgrass (Urochloa plantaginea), setaria grass (Setaria spp.), and fleabane (Conyza bonariensis) were also found.

The analysis of the participation of legumes showed that forage peanut was present in all grazing cycles. It was expressive in the winter, even being a tropical specie. The arrowleaf clover was present in five grazing cycles.

Table 1: Forage mass (pre-grazing) and botanical composition of the pasture in different forage systems

\begin{tabular}{|c|c|c|c|c|c|c|c|c|c|c|}
\hline \multirow{3}{*}{ FS } & \multicolumn{8}{|c|}{ Grazing cycles } & \multirow{3}{*}{ Mean } & \multirow{3}{*}{$\mathrm{CV}(\%)$} \\
\hline & $\mathbf{1}^{\mathrm{o}}$ & $2^{\circ}$ & $3^{\circ}$ & $4^{\circ}$ & $5^{\circ}$ & $6^{\circ}$ & $7^{\circ}$ & $8^{\circ}$ & & \\
\hline & Ago/13 & Sep/13 & Oct/13 & Nov/13 & Jan/14 & Feb/14 & Mar/14 & Apr/14 & & \\
\hline \multicolumn{11}{|c|}{ Pasture forage mass ( $\mathrm{t}$ of $\left.\mathrm{DM} \mathrm{ha}{ }^{-1}\right)$} \\
\hline $\mathrm{WL}^{1}$ & $2.1^{\mathrm{H}}$ & $1.8^{\mathrm{H}}$ & $5.1^{\mathrm{BC}}$ & $2.9^{\mathrm{G}}$ & $5.4^{\mathrm{B}}$ & $2.9^{\mathrm{G}}$ & $4.2^{\mathrm{DE}}$ & $3.4^{\mathrm{EFG}}$ & 3.5 & 4.9 \\
\hline $\mathrm{AC}^{2}$ & $2.0^{\mathrm{H}}$ & $1.9^{\mathrm{H}}$ & $5.8^{\mathrm{AB}}$ & $3.1^{\mathrm{G}}$ & $5.1^{\mathrm{BC}}$ & $3.6^{\mathrm{EFG}}$ & $5.0^{\mathrm{BC}}$ & $3.9^{\mathrm{DEF}}$ & 3.8 & 4.4 \\
\hline $\mathrm{FP}^{3}$ & $1.8^{\mathrm{H}}$ & $1.6^{\mathrm{H}}$ & $5.8^{\mathrm{AB}}$ & $3.7^{\mathrm{DEFG}}$ & $6.5^{\mathrm{A}}$ & $3.2^{\mathrm{FG}}$ & $4.4^{\mathrm{CD}}$ & $4.4^{\mathrm{CD}}$ & 3.9 & 4.3 \\
\hline $\mathrm{CV}(\%)$ & 14.1 & 15.7 & 5.0 & 8.6 & 4.9 & 8.6 & 6.1 & 7.0 & & \\
\hline \multicolumn{11}{|c|}{ Elephant grass $(\%)$} \\
\hline WL & - & - & 12.0 & 15.8 & $23.2^{b}$ & $44.3^{b}$ & $44.9^{b}$ & $32.9^{b}$ & 28.9 & 16.6 \\
\hline $\mathrm{AC}$ & - & - & 20.5 & 21.1 & $36.9^{\mathrm{a}}$ & $56.2^{\mathrm{a}}$ & $64.2^{\mathrm{a}}$ & $44.4^{\mathrm{a}}$ & 40.5 & 11.8 \\
\hline FP & - & - & 20.4 & 18.3 & $24.3^{\mathrm{b}}$ & $42.8^{b}$ & $46.2^{b}$ & $37.8^{a b}$ & 31.6 & 15.1 \\
\hline $\mathrm{CV}(\%)$ & & & 21.7 & 20.8 & 13.6 & 8.0 & 7.4 & 10.0 & & \\
\hline \multicolumn{11}{|c|}{ Elephant grass senescente material (\%) } \\
\hline WL & - & - & 1.4 & 0.7 & 0.8 & 1.7 & 2.8 & 1.1 & 1.4 & 18.8 \\
\hline $\mathrm{AC}$ & - & - & 2.9 & 3.8 & 0.9 & 1.9 & 3.3 & 1.9 & 2.4 & 11.6 \\
\hline FP & - & - & 0.3 & 1.2 & 1.2 & 0.9 & 2.2 & 1.9 & 1.3 & 22.4 \\
\hline $\mathrm{CV}(\%)$ & & & 24.4 & 19.1 & 26.3 & 23.7 & 13.8 & 21.4 & & \\
\hline \multicolumn{11}{|c|}{ Spontaneous species (\%) } \\
\hline WL & $17.6^{\mathrm{EFG}}$ & $29.5^{\mathrm{DE}}$ & $17.5^{\mathrm{FG}}$ & $43.8^{\text {в }}$ & $59.5^{\mathrm{A}}$ & $41.5^{\text {вс }}$ & 47.8 Ав & $60.0^{\mathrm{A}}$ & 39.6 & 3.0 \\
\hline $\mathrm{AC}$ & $6.0^{\mathrm{I}}$ & $29.0^{\mathrm{DE}}$ & $8.1^{\mathrm{I}}$ & $25.7^{\mathrm{DEF}}$ & $43.1^{\mathrm{BC}}$ & $33.4^{\mathrm{CD}}$ & $30.2^{\mathrm{CDE}}$ & $46.7^{\mathrm{AB}}$ & 27.8 & 3.7 \\
\hline FP & $22.7^{\mathrm{EF}}$ & $27.1^{\mathrm{DE}}$ & $11.7^{\mathrm{H}}$ & $16.5^{\mathrm{G}}$ & $34.1^{\mathrm{BCD}}$ & $22.6^{\mathrm{EF}}$ & $21.2^{\mathrm{EFG}}$ & $24.9^{\mathrm{DEF}}$ & 22.6 & 3.9 \\
\hline $\mathrm{CV}(\%)$ & 4.7 & 5.7 & 2.3 & 3.7 & 6.8 & 4.7 & 5.8 & 6.5 & & \\
\hline \multicolumn{11}{|c|}{ Legumes $(\%)$} \\
\hline $\mathrm{AC}$ & $3.5^{\mathrm{E}}$ & $3.1^{\mathrm{E}}$ & $20.2^{\mathrm{CD}}$ & $21.8^{\text {вCD }}$ & $12.4^{\mathrm{DE}}$ & - & - & - & 12.2 & 23.1 \\
\hline FP & $18.8^{\mathrm{CD}}$ & $34.6^{\mathrm{A}}$ & $23.7^{\mathrm{BC}}$ & $33.5^{\mathrm{A}}$ & $31.1^{\mathrm{AB}}$ & $26.9 \mathrm{ABC}$ & $28.1^{\mathrm{ABC}}$ & $30.6^{\mathrm{AB}}$ & 28.4 & 7.1 \\
\hline $\mathrm{CV}(\%)$ & 29.0 & 21.2 & 18.2 & 14.5 & 18.4 & & & & & \\
\hline \multicolumn{11}{|c|}{ Ryegrass (\%) } \\
\hline WL & $29.8^{\mathrm{BCDE}}$ & $38.5^{\text {вс }}$ & $60.1^{\mathrm{A}}$ & $7.0^{\mathrm{F}}$ & - & - & - & - & 33.8 & 13.8 \\
\hline $\mathrm{AC}$ & $18.5^{\mathrm{E}}$ & $33.9^{\text {вСD }}$ & $42.6^{\mathrm{B}}$ & $2.7^{\mathrm{G}}$ & - & - & - & - & 24.4 & 19.2 \\
\hline FP & $26.3^{\mathrm{CDE}}$ & $21.7^{\mathrm{DE}}$ & $37.0^{\mathrm{BC}}$ & $2.5^{\mathrm{G}}$ & - & - & - & - & 21.9 & 21.5 \\
\hline $\mathrm{CV}(\%)$ & 18.3 & 13.4 & 9.2 & 10.0 & & & & & & \\
\hline \multicolumn{11}{|c|}{ Dead material between rows $(\%)$} \\
\hline WL & $52.6^{\mathrm{B}}$ & $32.0^{\mathrm{C}}$ & $9.4^{\mathrm{EFG}}$ & $32.9^{\mathrm{C}}$ & $17.0^{\mathrm{D}}$ & $14.2^{\mathrm{D}}$ & $5.4^{\mathrm{H}}$ & $6.1^{\mathrm{H}}$ & 21.2 & 3.3 \\
\hline $\mathrm{AC}$ & $72.0^{\mathrm{A}}$ & $34.0^{\mathrm{C}}$ & 7.7 EFGH & $26.3^{\mathrm{C}}$ & $7.4^{\mathrm{FGH}}$ & $9.8^{\mathrm{EF}}$ & $2.4^{\mathrm{J}}$ & $6.9^{\mathrm{GH}}$ & 20.8 & 3.5 \\
\hline FP & $32.2^{\mathrm{C}}$ & $16.6^{\mathrm{D}}$ & $7.0^{\mathrm{GH}}$ & $26.9^{\mathrm{C}}$ & $10.0^{\mathrm{E}}$ & $7.4^{\mathrm{FGH}}$ & $2.2^{\mathrm{J}}$ & $3.7^{\mathrm{I}}$ & 13.3 & 4.3 \\
\hline $\mathrm{CV}(\%)$ & 4.1 & 4.3 & 9.8 & 7.2 & 4.6 & 5.8 & 5.2 & 4.5 & & \\
\hline
\end{tabular}

${ }^{1} \mathrm{WL}=$ elephant grass without legume (control); ${ }^{2} \mathrm{AC}=$ elephant grass + arrowleaf clover; ${ }^{3} \mathrm{FP}=$ elephant grass + forage peanut; DM $=$ dry matter; $\mathrm{CV}=$ coefficient of variation. Different letters, capital in the set, small in the column, are significantly different (Pd"0.05). 
The average participation of these legumes in the pasture composition were close to those recommended by Cadish et al. (1994), between 12 and $23 \%$, as adequate for the sustainability of the forage system.

There were found differences $(P \leq 0.05)$ in the contribution of ryegrass, with greater participation in the system without legumes. This result was due to the presence of legumes that interfere in the development of the associated grass (Paulino et al., 2008), the presence of ryegrass during the winter and of spontaneous species in the summer, as observed in a study conducted in similar conditions in the same region Diehl et al., 2014).

There were found differences $(\mathrm{P} \leq 0.05)$ for the dead material fraction of the forage present between rows, with a higher presence of dead material in the system without legume and in the intercropping with arrowleaf clover. This was possibly caused by the greater participation of spontaneous species in these systems, contributing with

Table 2: Forage mass (post-grazing) and botanical composition of pasture in different forage systems

\begin{tabular}{|c|c|c|c|c|c|c|c|c|c|c|}
\hline \multirow{3}{*}{$\begin{array}{l}\text { FS } \\
\text { Ago/13 }\end{array}$} & \multicolumn{7}{|c|}{ Grazing cycles } & \multirow[b]{2}{*}{$8^{\circ}$} & \multirow{3}{*}{ Mean } & \multirow{3}{*}{$\mathrm{CV}(\%)$} \\
\hline & $\mathbf{1}^{\mathrm{o}}$ & $2^{\circ}$ & $3^{\circ}$ & $4^{\circ}$ & $5^{\circ}$ & $6^{\circ}$ & $7^{\circ}$ & & & \\
\hline & Sep/13 & Oct/13 & Nov/13 & Jan/14 & Feb/14 & Mar/14 & Apr/14 & & & \\
\hline \multicolumn{11}{|c|}{ Pasture forage mass ( $\mathrm{t}$ of $\mathrm{DM} \mathrm{ha}^{-1}$ ) } \\
\hline $\mathrm{WL}^{1}$ & 1.4 & 1.4 & 3.9 & 2.0 & 2.9 & 1.9 & 2.5 & 2.4 & 2.3 & 6.4 \\
\hline $\mathrm{AC}^{2}$ & 1.3 & 1.3 & 3.9 & 1.8 & 3.0 & 1.7 & 2.4 & 2.6 & 2.2 & 6.5 \\
\hline $\mathrm{FP}^{3}$ & 1.1 & 1.2 & 3.9 & 2.2 & 3.8 & 2.0 & 2.2 & 2.6 & 2.4 & 6.1 \\
\hline $\mathrm{CV}(\%)$ & 15.1 & 14.3 & 4.9 & 9.4 & 5.9 & 10.3 & 8.0 & 7.5 & & \\
\hline \multicolumn{11}{|c|}{ Elephant grass $(\%)$} \\
\hline WL & - & - & $0.7^{\mathrm{G}}$ & $1.8^{\mathrm{F}}$ & $7.4^{\mathrm{C}}$ & $22.6^{\mathrm{AB}}$ & $21.4^{\text {в }}$ & $21.1 \mathrm{AB}$ & 12.5 & 12.5 \\
\hline $\mathrm{AC}$ & - & - & $0.7^{\mathrm{G}}$ & $3.9^{\mathrm{DE}}$ & $19.7^{\text {в }}$ & $34.5^{\mathrm{A}}$ & $37.4^{\mathrm{A}}$ & $29.3^{\mathrm{AB}}$ & 20.9 & 20.9 \\
\hline FP & - & - & $3.5^{\mathrm{E}}$ & $4.8^{\mathrm{CD}}$ & $7.0^{\mathrm{CD}}$ & $27.8 \mathrm{AB}$ & $26.3^{\mathrm{AB}}$ & $24.8^{\mathrm{AB}}$ & 15.7 & 15.7 \\
\hline $\mathrm{CV}(\%)$ & & & 27.4 & 15.0 & 10.9 & 5.5 & 8.5 & 4.5 & & \\
\hline \multicolumn{11}{|c|}{ Elephant grass senescente material (\%) } \\
\hline WL & - & - & $0.1^{\mathrm{G}}$ & $0.5^{\mathrm{FG}}$ & $0.7^{\mathrm{F}}$ & $2.0^{\mathrm{CDEF}}$ & $2.0^{\mathrm{CDEF}}$ & $1.1^{\mathrm{DEF}}$ & 1.1 & 15.5 \\
\hline $\mathrm{AC}$ & - & - & $0.1^{\mathrm{G}}$ & $0.9^{\mathrm{EF}}$ & $1.6^{\mathrm{DEF}}$ & $2.3^{\mathrm{BCDE}}$ & $6.3^{\mathrm{A}}$ & $4.2^{\mathrm{AB}}$ & 2.6 & 9.4 \\
\hline FP & - & - & $0.1^{\mathrm{G}}$ & $0.9^{\mathrm{EF}}$ & $0.6^{\mathrm{F}}$ & $1.6^{\mathrm{DEF}}$ & $2.4^{\mathrm{BCD}}$ & $2.9^{\mathrm{BC}}$ & 1.4 & 12.7 \\
\hline $\mathrm{CV}(\%)$ & & & 19.9 & 24.6 & 11.1 & 21.3 & 12.8 & 10.7 & & \\
\hline \multicolumn{11}{|c|}{ Spontaneous species $(\%)$} \\
\hline WL & 25.2 & 34.1 & 32.3 & $41.4^{\mathrm{a}}$ & $72.1^{\mathrm{a}}$ & $62.8^{a}$ & $65.6^{\mathrm{a}}$ & $69.3^{a}$ & 50.4 & 6.7 \\
\hline $\mathrm{AC}$ & 16.1 & 32.0 & 25.7 & $35.1^{\mathrm{ab}}$ & $53.3^{\mathrm{b}}$ & $49.7^{\mathrm{a}}$ & $45.0^{\mathrm{b}}$ & $51.9^{\mathrm{b}}$ & 38.6 & 8.7 \\
\hline FP & 13.9 & 26.5 & 21.9 & $26.8^{\mathrm{b}}$ & $41.3^{\mathrm{b}}$ & $25.1^{\mathrm{b}}$ & $39.7^{\mathrm{b}}$ & $39.9^{b}$ & 29.4 & 11.5 \\
\hline $\mathrm{CV}(\%)$ & 25.7 & 15.3 & 17.8 & 13.7 & 8.5 & 10.3 & 9.4 & 8.8 & & \\
\hline \multicolumn{11}{|c|}{ Legumes (\%) } \\
\hline $\mathrm{AC}$ & $0.5^{\mathrm{F}}$ & $1.9^{\mathrm{F}}$ & $20.5^{\mathrm{CD}}$ & 12.7 DEF & $8.8^{\mathrm{EF}}$ & - & - & - & 8.9 & 41.6 \\
\hline FP & $36.6^{\mathrm{A}}$ & $37.2^{\mathrm{A}}$ & $25.4^{\mathrm{BC}}$ & $32.1 \mathrm{AB}$ & $31.9 \mathrm{AB}$ & $33.8^{\mathrm{AB}}$ & $18.4^{\mathrm{CDE}}$ & $22.8^{\mathrm{BCD}}$ & 29.8 & 7.7 \\
\hline $\mathrm{CV}(\%)$ & 28.4 & 23.4 & 19.9 & 20.4 & 22.4 & & & & & \\
\hline \multicolumn{11}{|c|}{ Ryegrass (\%) } \\
\hline WL & 19.8 & 19.1 & 52.5 & - & - & - & - & - & 30.5 & 11.7 \\
\hline $\mathrm{AC}$ & 24.1 & 17.5 & 39.2 & - & - & - & - & - & 26.9 & 12.7 \\
\hline FP & 19.5 & 11.1 & 39.9 & - & - & - & - & - & 23.5 & 14.6 \\
\hline $\mathrm{CV}(\%)$ & 17.2 & 21.6 & 7.8 & & & & & & & \\
\hline \multicolumn{11}{|c|}{ Dead material between rows $(\%)$} \\
\hline WL & 55.0 & 46.8 & 14.5 & 56.3 & 20.2 & 12.6 & 11.0 & 8.5 & 28.1 & 4.4 \\
\hline $\mathrm{AC}$ & 59.6 & 48.5 & 13.9 & 47.4 & 16.7 & 13.4 & 11.4 & 14.7 & 28.2 & 4.4 \\
\hline FP & 30.0 & 25.3 & 9.3 & 35.5 & 19.3 & 11.6 & 13.3 & 9.5 & 19.2 & 4.9 \\
\hline $\mathrm{CV}(\%)$ & 2.7 & 5.5 & 16.1 & 1.9 & 9.9 & 6.0 & 8.6 & 8.8 & & \\
\hline
\end{tabular}

${ }^{1} \mathrm{WL}=$ elephant grass without legume (control); ${ }^{2} \mathrm{AC}=$ elephant grass + arrowleaf clover; ${ }^{3} \mathrm{FP}=$ elephant grass + forage peanut; DM = dry matter; $\mathrm{CV}=$ coefficient of variation. Different letters, capital in the set, small in the column, are significantly different $(\mathrm{P} \leq 0.05)$. 
senescent material, because of the trampling by the cows and selection of more desirable fodder. The values were high in the first grazing, during which period of spontaneous growth of the summer cycle, due to frost and low temperatures.

There was interaction $(\mathrm{P} \leq 0.05)$ for the residual forage mass (Table 2) between forage system and grazing cycle for elephant grass, dead material of this species, and for the presence of legumes.

There were found no effect of forage system on the residual forage, showing that the adjustment of the stocking density was similar among the systems. Similar behavior was observed with elephant grass, owing to the preference for this forage, as can be seen by the low residual forage mass values in relation to those of pre-grazing. The fraction of residual senescent material of elephant grass remained low, indicating that losses by trampling were low.

The participation of spontaneous species showed differences $(\mathrm{P} \leq 0.05)$ among the forage systems. It was associated $(r=0.90)$ with the initial forage mass, with greater participation in the system without legumes. The percentage of the contribution of these species were higher than the pre-grazing, indicating that spontaneous species are less consumed by the cows than the other species in the study such as elephant grass and arrowleaf clover.

No treatment effect was found for the participation of ryegrass, indicating uniform consumption of this forage in the different systems. Also, no differences were found among the forage systems for the fraction of dead material of the forage present between rows, being greater than the initial participation. This is because the cows preferred to seek green forage and there were losses caused by trampling. The higher values recorded in August and September were due to the effect of the cold and the frosts on the spontaneous species, which are most summer cycle species; and in November, due to the ryegrass senescence. Increased forage loss in this pasture occurs due to trampling, since the species present between rows are shorter and suffer a greater impact than the elephant grass, which has a more erect structure and low losses, because the animals walk between the tussocks (Meinerz et al., 2011).

There was interaction $(\mathrm{P} \leq 0.05)$ between forage system and grazing cycle for the pasture productive variables forage accumulation rate and forage production (Table 3). Daily forage accumulation rate showed differences $(\mathrm{P} \leq$ $0.05)$, with a higher prevalence in the intercropping systems. In the first grazing cycle the value was low, considering the period of introduction of arrowleaf clover, in May, until grazing in August, whereas the highest values were recorded in February and March, due to the participation of elephantgrass (Table 1).

Forage production of the intercropping treatments were similar, but higher $(\mathrm{P} \leq 0.05)$ than the system without legume. This result corroborates the findings of Azevedo

Table 3: Forage production and grazing efficiency in different forage systems

\begin{tabular}{|c|c|c|c|c|c|c|c|c|c|c|}
\hline \multirow{3}{*}{ FS } & \multicolumn{8}{|c|}{ Grazing cycles } & \multirow{3}{*}{ Mean } & \multirow{3}{*}{$\mathrm{CV}(\%$} \\
\hline & $\mathbf{1}^{\mathbf{0}}$ & $2^{\circ}$ & $3^{\circ}$ & $4^{\circ}$ & $\mathbf{5}^{\circ}$ & $6^{\circ}$ & $7^{\circ}$ & $\mathbf{8}^{\circ}$ & & \\
\hline & Ago/13 & Sep/13 & Oct/13 & Nov/13 & Jan/14 & Feb/14 & Mar/14 & Apr/14 & & \\
\hline \multicolumn{11}{|c|}{ Accumulation rate $\left(\mathrm{kg}\right.$ of $\left.\mathrm{DM} \mathrm{ha}^{-1} \mathrm{day}^{-1}\right)$} \\
\hline $\mathrm{WL}^{1}$ & $14.2^{\mathrm{I}}$ & $23.1^{\mathrm{GHI}}$ & $69.0^{\mathrm{c}}$ & $20.7^{\mathrm{HI}}$ & $66.0^{\mathrm{CD}}$ & 96.8 АВ & $75.7^{\mathrm{C}}$ & $53.7^{\mathrm{D}}$ & 52.4 & 6.9 \\
\hline $\mathrm{AC}^{2}$ & $8.3^{\mathrm{J}}$ & $38.5^{\mathrm{EF}}$ & $84.8^{\mathrm{BC}}$ & $24.9^{\mathrm{GH}}$ & $85.0^{\mathrm{BC}}$ & $110.2^{\mathrm{A}}$ & $113.4^{\mathrm{A}}$ & $51.0^{\mathrm{DE}}$ & 64.5 & 5.6 \\
\hline $\mathrm{FP}^{3}$ & $17.0^{\mathrm{I}}$ & $21.1^{\mathrm{HI}}$ & $79.2^{\mathrm{c}}$ & $32.0^{\mathrm{FG}}$ & 83.7 вС & $111.0^{\mathrm{A}}$ & $84.3^{\text {вС }}$ & $80.3^{\mathrm{C}}$ & 63.6 & 5.6 \\
\hline$\underline{\mathrm{CV}}(\%)$ & 12.4 & 17.0 & 7.6 & 11.0 & 11.4 & 6.0 & 9.5 & 5.8 & & \\
\hline \multicolumn{11}{|c|}{ Forage production $\left(\mathrm{kg}\right.$ of $\left.\mathrm{DM} \mathrm{ha}{ }^{-1}\right) *$} \\
\hline WL & $1.0^{\mathrm{EF}}$ & $0.6^{\mathrm{FGH}}$ & $3.9^{\mathrm{B}}$ & $0.5^{\mathrm{H}}$ & $3.6^{\mathrm{B}}$ & $2.3^{\mathrm{C}}$ & $2.3^{\mathrm{C}}$ & $1.6^{\mathrm{D}}$ & 2.0 & 1.1 \\
\hline $\mathrm{AC}$ & $0.6^{\mathrm{GH}}$ & $1.1^{\mathrm{DEF}}$ & $4.8^{\mathrm{A}}$ & $0.8^{\mathrm{EF}}$ & $3.8^{\text {в }}$ & $2.6^{\mathrm{C}}$ & $3.5^{\text {в }}$ & $1.6^{\mathrm{D}}$ & 2.3 & 1.1 \\
\hline FP & $1.2^{\mathrm{DE}}$ & $0.6^{\mathrm{GH}}$ & $4.5^{\mathrm{AB}}$ & $0.8^{\mathrm{EFG}}$ & $4.5^{\mathrm{AB}}$ & $2.6^{\mathrm{C}}$ & $2.5^{\mathrm{C}}$ & $2.4^{\mathrm{C}}$ & 2.4 & 1.0 \\
\hline $\mathrm{CV}(\%)$ & 2.9 & 3.7 & 0.8 & 1.0 & 1.4 & 1.0 & 1.3 & 0.8 & & \\
\hline \multicolumn{11}{|c|}{ Grazing efficiency (\%) } \\
\hline WL & 34.8 & 25.3 & 22.6 & 31.6 & 44.5 & 35.1 & 39.4 & 28.9 & 32.8 & 9.1 \\
\hline $\mathrm{AC}$ & 29.9 & 29.8 & 32.5 & 40.5 & 41.0 & 53.4 & 52.6 & 34.1 & 39.2 & 7.6 \\
\hline FP & 37.9 & 22.9 & 31.8 & 39.1 & 41.5 & 35.6 & 49.7 & 41.6 & 37.5 & 7.9 \\
\hline CV (\%) & 17.1 & 22.6 & 20.2 & 15.8 & 13.8 & 14.2 & 12.4 & 16.8 & & \\
\hline
\end{tabular}

${ }^{1} \mathrm{WL}=$ elephant grass without legume (control); ${ }^{2} \mathrm{AC}=$ elephant grass + arrowleaf clover; ${ }^{3} \mathrm{FP}=$ elephant grass + forage peanut; DM $=$ dry matter; $\mathrm{CV}=$ coefficient of variation. Different letters, capital in the set, small in the column, are significantly different $(\mathrm{P} \leq 0.05)$. Total forage production of $15.7 ; 18.7$ and 19.4 tons of $\mathrm{DM} \mathrm{ha}^{-1}$ year $^{-1}$ for the systems without legume, with arrowleaf clover and forage peanut, respectively. 
Junior et al. (2012) and Diehl et al. (2014) for the intercropping of elephant grass and red clover.

The grazing efficiency values had no influence from the forage system. It is worth noting that the mean value of $36.5 \%$ shows that there was no limit on consumption per animal, which according to Delagarde et al. (2001) occurs when grazing efficiency exceeds $50 \%$. The forage utilization is considered low, as it is associated with the diversity of pasture composition and the management prioritized the most important crops such as elephant grass, ryegrass, and legumes.

\section{CONCLUSIONS}

The introduction of legumes into the system results in higher mass and forage production, without affecting grazing efficiency. The presence of legumes contributes to increase forage production of the companion grass (elephant grass) and control spontaneous species.

\section{REFERENCES}

Assmann AL, Pelissari A, Moraes A, Assmann TS, Oliveira EB \& Sandini I (2004) Produção de gado de corte e acúmulo de matéria seca em sistema de integração lavoura-pecuária em presença e ausência de trevo branco e nitrogênio. Revista Brasileira de Zootecnia, 33:37-44.

Azevedo Junior RL, Olivo CJ, Meinerz GR, Agnolin CA, Diehl MS, Moro G, Parra CLC, Quatrin MP \& Horst T (2012) Produtividade de sistemas forrageiros consorciados com amendoim forrageiro ou trevo vermelho. Ciência Rural, 42:2043-2050.

Barcellos AO, Ramos AKB, Vilela L \& Martha Junior GB (2008) Sustentabilidade da produção animal baseada em pastagens consorciadas e no emprego de leguminosas exclusivas, na forma de banco de proteína, nos trópicos brasileiros. Revista Brasileira de Zootecnia, 37:51-67.

Burns JC, Pond KR \& Fisher DS (1994) Measurement of forage intake. In: Fahey Jr GC (Ed.) Forage quality evaluation, and utilization. Wisconsin, American Society of Agronomy. p.494532 .

Cadish G, Schunke RM \& Giller KE (1994) Nitrogen cycling in a pure grass pasture and a grass-legume misture on a red latosol in Brazil. Tropical Grasslands, 28:43-52.

CQFS - Comissão de Química e Fertilidade do Solo (2004) Manual de adubação e calagem para os estados do Rio Grande do Sul e Santa Catarina. Porto Alegre, SBCSNRS. 400p.

Dall'Agnol M, Nabinger C \& Montardo DP (2002) Estado atual e futuro da produção e utilização de leguminosas forrageiras na Zona Campos. In: 19 ${ }^{\mathrm{a}}$ Reunión de Grupo Técnico en Forrajeras del Cono Sur Zona Campos, Mercedes. Anais, INTA. p.83-90.

Delagarde R, Prache S, D'Hour P \& Petit M (2001) Ingestion de l'herbe par les ruminants au paturage. Fourrages, 166:189-212.

Diehl MS, Olivo CJ, Agnolin CA, Azevedo Júnior RL, Bratz VF \& Santos JC (2014) Massa de forragem e valor nutritivo de capim elefante, azevém e espécies de crescimento espontâneo consorciadas com amendoim forrageiro ou trevo vermelho. Ciência Rural, 44:1845-1852.

Hodgson J (1979) Nomenclature and definitions in grazing studies. Grass and Forage Science, 34:11-18.
INMET - Instituto Nacional De Meteorologia (2014) Banco de dados meteorológicos para ensino e pesquisa. Dados mensais Estação Meteorológica de Santa Maria 2013-2014. Brasília, INMET. Disponível em: <http://www.inmet.gov.br/portal/>. Acessado em: 15 de junho de 2014.

't Mannetje L (2000) Measuring biomass of grassland vegetation. In: 't Mannetje L \& Jones RM (Eds.) Field and laboratory methods for grass land and animal production research. Cambridge, CABI. p.51-178.

Meinerz GR, Olivo CJ, Agnolin CA, Dullius AP, Moraes RS, Mombach G, Foletto V \& Machado PR (2011) Produção e valor nutritivo da forragem de capim-elefante em dois sistemas de produção. Revista Brasileira de Zootecnia, 40:2673-2680.

Moreno JA (1961) Clima do Rio Grande do Sul. Porto Alegre, Secretaria da Agricultura. 41p.

Olivo CJ, Charão PS, Pereira LET, Ziech MF, Meinerz G \& Tyska D (2007) Produtividade e valor nutritivo de pasto de capimelefante manejado sob princípios agroecológicos. Revista Brasileira de Zootecnia, 36:1729-1735.

Paulino VT, Braga GJ, Lucena MAC, Gerdes L \& Colozza MT (2008) Sustentabilidade de pastagens consorciadas - ênfase em leguminosas forrageiras. In: II Encontro Sobre Leguminosas Forrageiras, Nova Odessa. Anais, IZ/APTA/SAA. p.01-55.

Pereira JM (2001) Produção e persistência de leguminosas em pastagens tropicais. In: $2^{\circ}$ Simpósio de Forragicultura e Pastagens, Lavras. Anais, UFLA. p.111-142.

SAS Institute Inc. (2001) Statistical Analysis System user's guide. Version 8,2. Cary, Statistical Analysis System Institute. 1686p.

Silva Neto B, Schneider M \& Viegas J (2006) Modelo de simulação de sistemas de pastejo rotativo e contínuo de azevém (Lolium multiflorum Lam.) na bovinocultura. Ciência Rural, 36:12721277.

Skonieski FR, Viégas J, Bermudes RF, Nörnberg JL, Ziech MF, Costa OAD \& Meinerz GR (2011) Composição botânica e estrutural e valor nutricional de pastagens de azevém consorciadas. Revista Brasileira de Zootecnia, 40:550-556.

Soares JPG, Berchielli TT, Aroeira LJM, Deresz F \& Verneque RS (2004) Estimativas de consumo do capim-elefante (Pennisetum purpureum Schum.), fornecido picado para vacas lactantes utilizando a técnica do óxido crômico. Revista Brasileira de Zootecnia, 33:811-820.

Steinwandter E, Olivo CJ, Santos JC, Araújo TLR, Aguirre PF \& Diehl MS (2009) Produção de forragem em pastagens consorciadas com diferentes leguminosas sob pastejo rotacionado. Acta Scientiarum Animal Sciences, 31:131-137.

Streck EV, Kämpf N, Dalmolin RSD, Klamt E, Schneider P \& Nascimento PC (2002) Solos do Rio Grande do Sul. Porto Alegre, EMATER/RS / Universidade Federal do Rio Grande do Sul. $126 \mathrm{p}$.

Teodoro RB, Oliveira FL \& Silva DMN (2010) Eficiência de leguminosas utilizadas na adubação verde no controle de plantas espontâneas. In: $27^{\circ}$ Congresso Brasileiro da Ciência das Plantas Daninhas, Ribeirão Preto. Anais, SBCPD. p.233-235.

Wrege MS, Steinmetz S, Reisser Júnior C \& Almeida IR (2011) Atlas climático da Região Sul do Brasil: Estados do Paraná, Santa Catarina e Rio Grande do Sul. In: Wrege MS, Steinmetz S, Reisser Júnior C \& Almeida IR (Eds.) Pelotas, Embrapa Clima Temperado / Colombo, Embrapa Florestas. 336p.

Rev. Ceres, Viçosa, v. 65, n.2, p. 174-180, mar/abr, 2018 